\title{
KAJIAN RANTAI PERSEDIAAN BARANG (SUPPLY CHAIN) AGROINDUSTRI TEMPE DI KABUPATEN JEMBER
}

\author{
${ }^{1}$ Astri Maesyaroh Ningtyas, ${ }^{2}$ Yuli Hariyati, dan ${ }^{3}$ Triana Dewi Hapsari \\ ${ }^{1}$ Dosen Prodi Agribisnis Fakultas Pertanian Universitas Bondowoso \\ ${ }^{2,3}$ Dosen Jurusan Sosial Ekonomi Pertanian Fakultas Pertanian Universitas Jember \\ email: astrimaesyarohningtyas@gmail.com
}

\begin{abstract}
"Tempe" is one of agroindustrial product which soybean is uesd as raw material. The increasing price of material causes the agroindustry run is unstable. Besides, keeping raw material in agroindustry werehouses is also costly. Therefore researh in raw material inventory is required. This reseacrh is aimed to describe, (1) supply chain, (2) economic order quantity; lead time ordering; reorder point of tempe agroindustry. The results showed that: (1) Supply chain on agroindustrial tempe in Jember showed a different pattern: (a) The Supplier of soybean - agroindustrial tempe - outlets - consumer (agroindustrial tempe "Makmur", "Rizqy") (b) The Supplier of soybean - agroindustrial tempe - consumer (agroindustrial tempe "Makmur", "Sumber Mas", "Pratama", "Rizqy", and "UD. Rahayu") (2) EOQ (Economic Order Quanttity) on agroindustrial tempe in Jember indicates of non economic result, because the total ordering cost is not equal to the total ordering cost; Lead time on Agroindustry of tempe in Jember is 0,02 day (agroindustrial tempe "Makmur"), 0,25 day (agroindustrial tempe "Sumber Mas"), 0,02 day (agroindustrial tempe "Pratama"), 0,04 day (agroindustrial tempe "Rizqy"), and 0,04 day (agroindustrial tempe "UD. Rahayu"); Reorder point of feedstock (soybean) in agroindustrial tempe in Jember is $1.5 \mathrm{~kg}$ (agroindustrial tempe "Makmur"), $250 \mathrm{~kg}$ (agroindustrial tempe "Sumber Mas"), $2 \mathrm{~kg}$ (agroindustrial tempe "Pratama"), $4 \mathrm{~kg}$ (agroindustrial tempe "Rizqy"), and $4 \mathrm{~kg}$ (agroindustrial tempe "UD. Rahayu”)
\end{abstract}

Keywords: Supply chain, economic order quantity, lead time ordering, reorder point.

\section{PENDAHULUAN}

Meningkatnya pertumbuhan penduduk di Indonesia secara langsung mempengaruhi pertumbuhan permintaan akan pangan. Hal itu disebabkan oleh pertambahan populasi dan perubahan pola pangan yang sejalan dengan pertumbuhan ekonomi. Dampak dari peningkatan pendapatan di masyarakat adalah perubahan pola pangan dari pola pangan karbohidrat tinggi dengan protein rendah menjadi pola pangan karbohidrat lebih rendah dengan protein yang lebih tinggi. Kedelai dianggap memiliki peluang yang besar untuk memenuhi suplai protein di masa yang akan datang serta berperan dalam industri pakan ternak dan sebagai bahan baku pada berbagai industri pengolahan. Produk yang terbuat dari kedelai Indonesia telah dikenal di dunia internasional sebagai produk dengan nutrisi yang tinggi. Proses pengolahan kedelai diklasifikasi-kan menjadi dua yaitu (1) dengan fermentasi seperti tempe, kecap dan tauco, dan (2) tanpa fermentasi seperti tahu, susu kedelai, tepung kedelai, dan tauge. Produk-produk tersebut telah menjadi bagian dari menu makan sehari-hari bagi penduduk dari segala tingkatan masyarakat (Silitonga, dkk, 1996).

Salah satu agroindustri pangan yang keberadaannya sudah mendapat tempat di masyarakat adalah agroindustri yang mengolah kedelai menjadi tempe dan tahu. Tempe merupakan makanan hasil fermentasi kedelai sekaligus merupakan warisan budaya bangsa Indonesia yang tidak ternilai harga nya. Tempe juga merupakan salah satu makanan tradisional yang murah harganya, mudah didapat dan disukai masyarakat, serta sudah dapat diekspor ke luar negeri. Tempe mempunyai nilai gizi yang cukup besar. Selain mengandung protein sebesar $19,5 \%$, tempe juga mengandung lemak sekitar 4\%, karbohidrat 9,4\% dan vitamin B12 antara 3,9-5 mg per 100 gram tempe kedelai (Winarti, 1998).

Agroindustri tempe merupakan industri yang mengolah kedelai menjadi produk tempe yang siap dikonsumsi. Sesuai dengan ciri indus- 
tri rumah tangga dan industri kecil, maka unit agroindustri tempe adalah perorangan. Sumber modal investasi untuk peralatan dan modal kerja umumnya berasal dari pinjaman dan dana pengelola sendiri. Sedangkan tenaga kerja dalam agroindustri tempe biasanya berasal dari dalam keluarga dengan menggunakan teknologi produksi yang sederhana (Yuniasih, 2002).

Jumlah agroindustri tempe yang berbahan baku kedelai di Kabupaten Jember cukup banyak baik yang sudah memiliki ijin dari Dinas Koperasi dan Periondustrian maupun yang belum. Kabupaten Jember sebagai salah satu kabupaten di Jawa Timur banyak memiliki unit usaha yang mengolah bahan baku yang berasal dari hasil pertanian menjadi barang yang siap dikonsumsi oleh masyarakat mulai dari kalangan menengah bawah sampai atas, salah satunya agroindustri tempe. Bahan baku utama yang digunakan untuk mengolah tempe adalah kedelai. Berkaitan dengan hal ini, agroindustri tempe memerlukan persediaan bahan baku kedelai untuk kegiatan produksi yang dibutuhkan mendatang. Oleh karena itu, perencanaan dan pengendalian persediaan berguna untuk menjadikan proses produksi dan pemasaran stabil. Persediaan bahan baku bertujuan untuk mengurangi ketidakpastian produksi akibat fluktuasi pasokan bahan baku.

Beberapa penelitian terkait persediaan bahan baku telah banyak dilakukan. Diantaranya Andira (2016), Nurhasanah (2012), Robyanto dkk (2013), Riyadi (2012), Darmawan dkk (2015). Masing-masing fokus pada persediaan bahan baku untuk roti, solar, gula, abon lele, dan pia. Akan tetapi masih belum ada yang meneliti tentang persediaan bahan baku untuk produk tempe. Oleh karenanya penelitian ini fokus pada persediaan bahan baku untuk produk tempe.

Berdasarkan latar belakang yang telah dikemukakan di atas maka beberapa permasalahan yang ingin dikaji oleh peneliti antara lain mengenai rantai persediaan barang (supply chain), tingkat pemesanan ekonomis (Economic Order Quantity), rentang waktu (lead time) pemesanan bahan baku, dan titik pemesanan kembali (reorder point) kedelai pada agroindustri tempe di Kabupaten Jember.

\section{METODE PENELITIAN}

Penentuan daerah penelitian ini dilakukan dengan sengaja (purposive method) yaitu agroindustri tempe di Kabupaten Jember. Dasar pertimbangan pemilihan agroindustri tempe di Ka- bupaten Jember sebagai daerah penelitian adalah (1) Kabupaten Jember termasuk dalam 10 besar penghasil kedelai terbesar di Jawa Timur (2) Kabupaten Jember merupakan kabupaten yang lebih banyak terdapat agroindustri tempe daripada agroindustri tahu atau agroindustri olahan kedelai lainnya. Hal ini dikarenakan tempe merupakan salah satu produk fermentasi tradisional yang cukup terkenal, dan merupakan sumber protein nabati yang sangat potensial (3) Terdapat data agroindustri tempe yang tercatat pada Dinas Perindustrian, Perdagangan, dan ESDM Kabupaten Jember sampai dengan tahun 2012.

Metode yang digunakan dalam penelitian ini adalah metode deskriptif dan analitis. Metode deskriptif bertujuan untuk membuat gambaran atau lukisan secara sistematis, faktual, dan akurat mengenai fakta-fakta, sifat-sifat, serta hubungan antar fenomena yang diselidiki. Perspektif waktu yang dijangkau dalam penelitian deskriptif adalah waktu sekarang, atau sekurang-kurangnya jangka waktu yang masih terjangkau dalam ingatan responden. Metode analitis ditujukan untuk menguji hipotesis-hipotesis dan mengadakan interpretasi yang lebih dalam tentang hubungan-hubungan yang lebih banyak dibatasi oleh keperluan-keperluan pengukuran-pengukuran (Nazir, 2003).

Metode pengambilan sampel yang digunakan adalah metode total sampling. Total sampling adalah metode pengambilan contoh yang menggunakan seluruh populasi yang ada. Metode total sampling dilakukan dengan mengambil agroindustri tempe berbahan baku kedelai yang proses produksinya berkelanjutan hingga saat ini, jenis produksinya berdasarkan persediaan bahan baku (kedelai), dan merupakan agroindustri formal yang tercatat dan dinyatakan masih aktif di Disperindag dan ESDM Kabupaten Jember dari tahun 2008 s.d. Tahun 2014. Terdapat 5 agroindustri tempe yang bisa dijadikan sampel penelitian, yaitu: agroindustri tempe Makmur, Sumber Mas, Pratama, Rizqy, dan UD.Rahayu. Agroindustri yang termasuk dalam skala industri rumah tangga adalah agroindustri tempe Makmur, agroindustri tempe Pratama, agroindustri tempe Rizqy, dan agroindustri tempe UD. Rahayu, sedangkan agroindustri tempe Sumber Mas merupakan satu-satunya agroindustri dengan kategori skala industri kecil. Namun demikian, banyak usaha tempe yang tidak memiliki merek. Karenanya tidak dimasukkan dalam penelitian ini. 


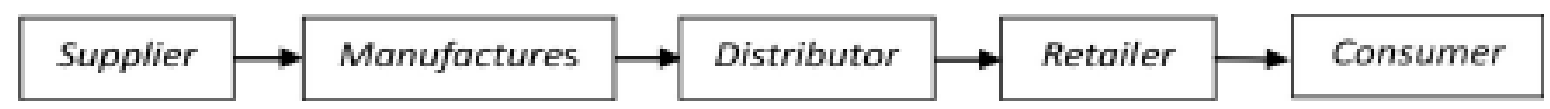

Gambar 1. Skema Supply Chain

Metode pengambilan data yang digunakan dalam penelitian ini adalah metode Interaktif dan non-interaktif. Metode Interaktif melalui wawancara dan observasi secara mendalam. Metode Non-interaktif meliputi kuisioner, mencatat dokumen dan arsip. Sumber data yang digunakan adalah data primer dan data sekunder. Data primer, yaitu data yang diperoleh langsung, yakni dari responden melalui metode wawancara berdasarkan daftar pertanyaan yang telah ditetapkan menggunakan kuisioner. Data sekunder, yaitu data yang diperoleh dari berbagai literatur, internet, maupun instansi terkait yang mendukung penelitian ini. Instansi-instansi yang berkaitan dengan penelitian ini yaitu Dinas Perindustrian, Perdagangan, dan ESDM Kabupaten Jember, dan BPS Kabupaten Jember.

Permasalahan pertama mengenai rantai persediaan barang (supply chain) pada agroindustri tempe di Kabupaten Jember dibahas menggunakan analisis deskriptif. Supply chain adalah suatu sistem tempat organisasi menyalurkan barang produksi dan jasanya kepada para pelanggannya. Konsep supply chain merupakan konsep baru dalam melihat persoalan logistik. Masalah logistik dilihat sebagai masalah yang lebih luas terbentang sangat panjang sejak dari barang dasar sampai barang jadi yang dipakai konsumen akhir yang dapat digambarkan menjadi mata rantai persediaan barang. Melihat definisi tersebut, dapat dikatakan bahwa supply chain adalah jaringan logistik. Dalam hubungan ini, ada beberapa pemain utama yang dapat dilihat pada gambar 1 .

Untuk menguji hipotesis tentang tingkat pemesanan bahan baku pada agroindustri tempe di Kabupaten Jember digunakan analisis Economic Order Quantity (EOQ) guna menentukan volume atau jumlah pemesanan yang paling ekonomis untuk dilaksanakan pada setiap kali pembelian bahan baku. Nilai Economic Order Quantity (EOQ) yang optimal/ ekonomis dapat diperoleh dengan menggunakan pendekatan tabel dan grafik/pendekatan formula. Cara lain untuk memperoleh EOQ dengan pendekatan matematika, dikenal dengan istilah cara formula (Herjanto, 1999), dirumuskan sebagai berikut:
Keterangan:

$$
E O Q=\sqrt{ } 2 \mathrm{DS} / \mathrm{H}
$$

$E O Q=$ Jumlah pembelian bahan baku yang ekonomis $(\mathrm{kg})$

$\mathrm{D}=$ Jumlah kebutuhan barang (unit/tahun)

$\mathrm{S} \quad=$ Biaya pemesanan $(\mathrm{Rp} /$ pesanan $)$

$\mathrm{H}$ = Biaya penyimpanan/unit bahan selama satu tahun (Rp)

Menurut Yamit (2002), kriteria pengambilan keputusan untuk analisis Economic Order Quantity (EOQ) adalah sebagai berikut:

1. Pemesanan bahan baku (kedelai) ekonomis apabila total biaya pemesanan (total ordering cost) $=$ total biaya simpan $($ total order ing cost).

2. Pemesanan bahan baku (kedelai) tidak ekonomis apabila total biaya pemesanan (total ordering cost) $\neq$ total biaya simpan (total ordering cost).

Rentang waktu pemesanan (lead time) bahan baku pada agroindustri tempe di Kabupaten Jember dibahas menggunakan analisis deskriptif. analisis deskriptif mem-berikan gambaran terhadap fenomena yang ada, mendapatkan makna dan implikasi dari suatu masalah yang ingin dipecahkan (Nasir, 2003).

Titik pemesanan kembali bahan baku (kedelai) pada agroindustri tempe di Kabupaten Jember dapat diketahui menggunakan analisis reorder point (ROP). Saat pemesanan kembali (reorder point) adalah waktu dimana pemesanan dilakukan dengan mempertimbangkan waktu tunggu sedemikian rupa sehingga pada saat tingkat persediaan mencapai nol maka persediaan baru sudah diterima. Analisis reorder point dilakukan dengan cara men-jumlahkan besarnya safety stock yang optimal selama periode tertentu dan pemakaian bahan baku selama waktu tenggang (lead time). Menurut Herjanto (1999), reorder point (ROP) dirumuskan sebagai berikut:

$$
\mathbf{R O P}=(\mathbf{d} \times \mathbf{L})+\mathrm{SS}
$$

Keterangan:

ROP = Titik pemesanan kembali $(\mathrm{kg})$

$\mathrm{d} \quad=$ Tingkat kebutuhan kedelai ( $\mathrm{kg} /$ hari)

$\mathrm{L} \quad=$ Lead time atau waktu tenggang (hari)

$\mathrm{SS} \quad=$ Persediaan pengaman kedelai $(\mathrm{kg})$ 


\section{HASIL DAN PEMBAHASAN}

Rantai Persediaan Barang (Supply Chain) pada Agroindustri Tempe di Kabupaten Jember

Rantai persediaan barang (supply chain) ini bertujuan untuk memberikan keuntungan kepada masing-masing pihak, baik itu Suppliers, Manufacturer, Distribustion, Retailer, dan Customers. Keuntungan itu antara lain dapat mengurangi biaya pemesanan barang, dapat menekan penimbunan barang, menjamin kelancaran penyediaan barang, menjaga mutu, dan lain sebagainya. Rantai persediaan barang (supply chain) yang ada pada Agroindustri Tempe di Kabupaten Jember menunjukkan pola yang beragam, tidak seperti pola supply chain yang pada umumnya Suppliers - Manufacturer-Distribustion - Retailer - Customers. Rantai persediaan barang (supply chain) dari setiap agroindustri memiliki pemasok bahan baku untuk proses produksinya dan ada yang memiliki perantara dalam penyaluran produk tempe yang dihasilkannya, ada yang tidak memiliki perantara, melainkan langsung dijual sendiri ke konsumen.

Berdasarkan gambar tersebut, dapat dijelaskan bahwa agroindustri tempe Makmur memiliki satu pemasok (supplier) yaitu Toko Adikarya yang ada di Kecamatan Ambulu. Agroindustri tempe Makmur tersebut memilih pemasok tersebut dikarenakan dari beberapa toko bahan baku yang ada di Kecamatan Ambulu, harga kedelai yang dijual adalah yang paling murah dibanding lainnya. Agroindustri tempe Makmur merupakan manufacturer yang melakukan pekerjaan membuat atau menyelesaikan barang (finishing) dalam hal ini untuk produk tempe kedelai. Kedelai dari pemasok diolah menjadi tempe kedelai, setelah pengolahan produk tempe kedelai selesai dan siap, produk tempe ini disalurkan ke konsumen. Daerah pemasaran tempe agroindustri tempe Makmur ini hanya di dalam kota, tepatnya di lingkungan sekitar lokasi produksi tempe yaitu Kecamatan Ambulu (Desa Tegalsari, Andongsari, Sumberejo, Sabrang, Pasar Ambulu) dan Kecamatan Wuluhan.

Agroindustri tempe Sumber Mas memiliki satu pemasok (supplier) yaitu Toko Rejeki Trunojoyo Jember. Agroindustri tempe Sumber Mas tersebut memilih pemasok tersebut dikarenakan dari beberapa toko bahan baku yang ada di sekitar lokasi produksi tempe, harga kedelai yang dijual adalah yang paling stabil harganya dibanding lainnya, serta karena sudah lama berlangganan, dari Toko Adikarya ini, agroindustri tempe Sumber Mas mendapat fasilitas pelanggan, yaitu untuk memenuhi persediaan bahan baku tempe, pemesanan kedelai tidak perlu diambil sendiri di toko, melainkan langsung diantar ke lokasi produksi tempe oleh pemasok. Kedelai yang dipesan untuk bahan baku produksi tempe di agroindustri tempe Sumber Mas tergolong besar jumlahnya.

Agroindustri tempe Sumber Mas merupakan manufacturer yang melakukan pekerjaan membuat atau menyelesaikan barang (finishing) dalam hal ini untuk produk tempe kedelai. Kedelai dari pemasok diolah menjadi tempe kedelai, setelah pengolahan produk tempe kedelai selesai dan siap, produk tempe ini disalurkan ke konsumen dengan cara dijual sendiri ke konsumen, baik ke konsumen potensial ataupun ke konsumen murni. Konsumen potensial yang dimaksud adalah pembeli yang membeli tempe untuk di jual kembali ke konsumen murni. Daerah pemasaran tempe agroindustri tempe Sumber Mas ini hanya di dalam wilayah kota, tepatnya di salah satu stand yang ada di Pasar Tanjung.

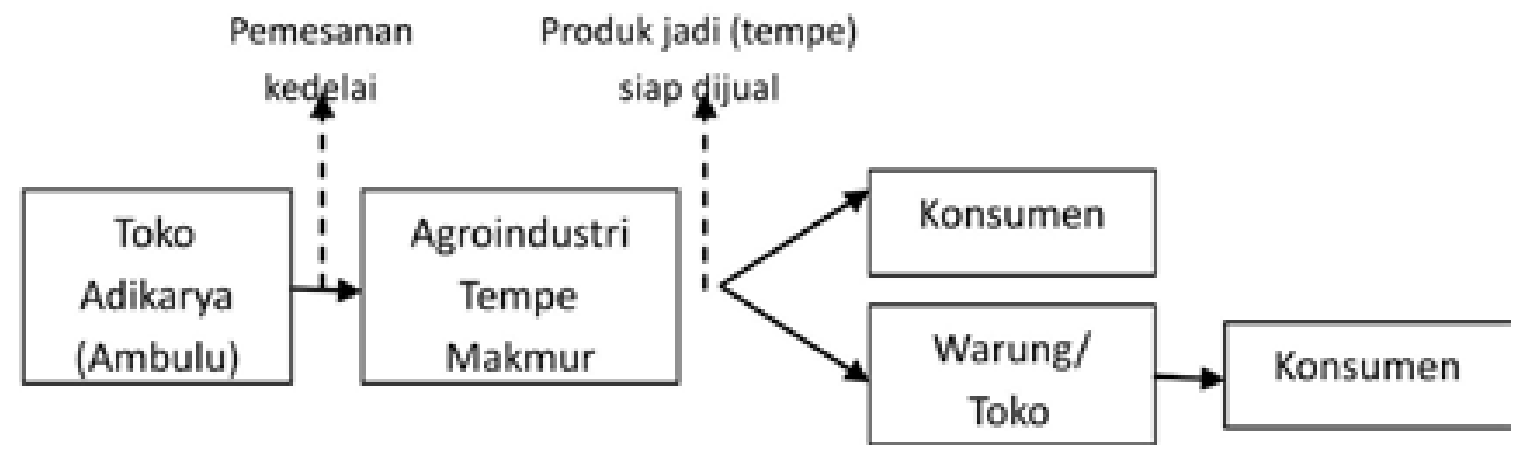

Gambar 2. Rantai Persediaan Barang (supply chain) pada Agroindustri Tempe Makmur di Kabupaten Jember 


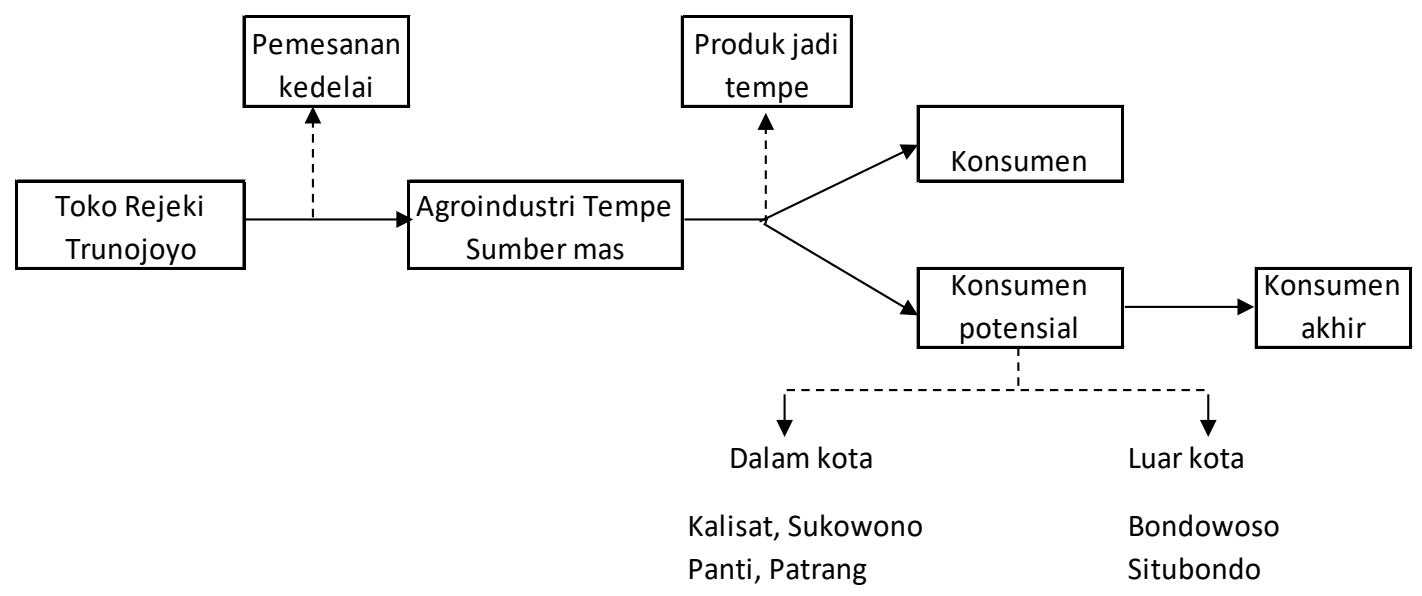

Gambar 3. Rantai Persediaan Barang (supply chain) pada Agroindustri Tempe Sumber Mas di Kabupaten Jember

Agroindustri tempe Pratama memiliki lebih dari satu pemasok (supplier) yaitu Toko Rejeki Trunojoyo Jember dan Toko Asen Gebang. Agroindustri tempe Pratama tersebut memilih kedua pemasok tersebut dikarenakan dari beberapa toko bahan baku yang ada di sekitar lokasi produksi tempe, harga kedelai yang dijual di kedua toko tersebut adalah yang paling stabil harganya dibanding lainnya, serta karena sudah lama berlangganan beli bahan baku di kedua toko tersebut. Memiliki lebih dari satu pemasok bahan baku bertujuan untuk mengatasi harga kedelai yang tidak stabil, sehingga kebutuhan bahan baku akan dapat terus terpenuhi tanpa hambatan.

Agroindustri tempe Pratama merupakan manufacturer yang melakukan pekerjaan membuat atau menyelesaikan barang (finishing) dalam hal ini untuk produk tempe kedelai. Kedelai dari pemasok diolah menjadi tempe kedelai, setelah pengolahan produk tempe kedelai selesai dan siap, produk tempe ini disalurkan ke konsumen dengan cara dijual sendiri di Pasar Tanjung.
Daerah pemasaran tempe agroindustri tempe Pratama ini hanya di dalam kota, yaitu dengan membuka dua stand di Pasar Tanjung. Penyaluran ke konsumen oleh Agroindustri Pratama sementara ini hanya melalui stand penjualan yang dijaga sendiri dan juga dengan stand penjualan yang dijaga oleh karyawan (tenaga kerja dalam keluarga).

Agroindustri tempe Rizqy memiliki satu pemasok (supplier) yaitu Toko Sinar Baru yang ada di Arjasa Jember. Agroindustri tempe Rizqy tersebut memilih pemasok tersebut dikarenakan dari beberapa toko bahan baku yang ada di Kecamatan Patrang, harga kedelai yang dijual adalah yang paling murah dibanding lainnya, serta karena sudah lama berlangganan. Pemenuhan kebutuhan pasokan bahan baku dari Toko Sinar Baru Arjasa ini juga dikarenakan letak lokasi produksi agroindustri tempe Rizqy yang dekat.

Agroindustri tempe Rizqy merupakan manufacturer yang melakukan pekerjaan membuat atau menyelesaikan barang (finishing) dalam hal ini untuk produk tempe kedelai. Kedelai dari

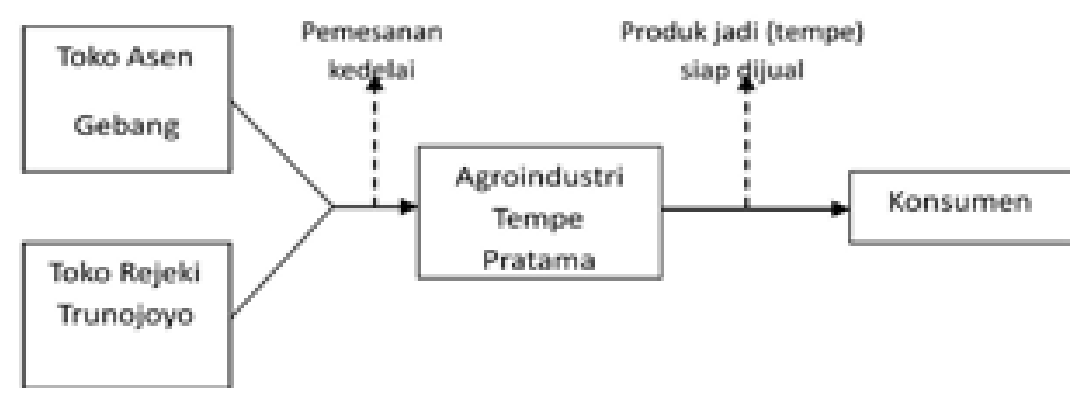

Gambar 4. Rantai Persediaan Barang (supply chain) pada Agroindustri Tempe Pratama di Kabupaten Jember 


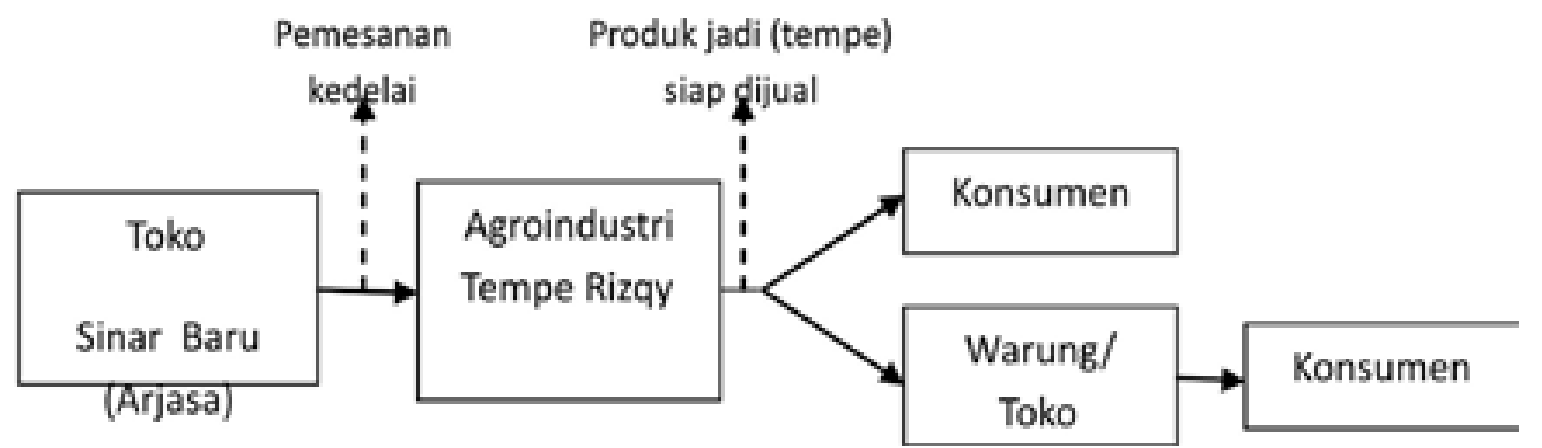

Gambar 5. Rantai Persediaan Barang (supply chain) pada Agroindustri Tempe Rizqy di Kabupaten Jember

pemasok diolah menjadi tempe kedelai, setelah pengolahan produk tempe kedelai selesai dan siap, produk tempe ini disalurkan ke konsumen dengan dua cara oleh agroindustri tempe Rizqy, yaitu sama seperti agroindustri tempe Makmur, cara pertama adalah dengan cara dijual sendiri ke konsumen, yaitu dengan berkeliling menggunakan sepeda motor dari rumah ke rumah dan membuka stand penjualan di Pasar Tanjung. Kemudian cara yang kedua, adalah dengan menitipkan produk tempe di warung/toko. Daerah pemasaran agroindustri tempe Rizqy ini hanya di dalam kota, tepatnya di lingkungan sekitar lokasi produksi tempe yaitu daerah Patrang, Baratan, dan di Pasar Tanjung.

Agroindustri tempe UD. Rahayu memiliki satu pemasok (supplier) yaitu Toko Asen Gebang. Agroindustri tempe UD. Rahayu tersebut memilih pemasok tersebut dikarenakan dari beberapa toko bahan baku yang ada di sekitar lokasi produksi tempe, harga kedelai yang dijual di toko tersebut adalah yang paling stabil harganya dibanding lainnya, serta karena sudah lama berlangganan di kedua toko tersebut dan lokasi toko dengan lokasi produksi tergolong yang terdekat.

Agroindustri tempe UD. Rahayu dalam rantai persediaan barang (supply chain) merupakan manufacturer yang melakukan pekerjaan membuat atau menyelesaikan barang (finishing) produk tempe kedelai. Kedelai dari pemasok diolah menjadi tempe, setelah pengolahan produk tempe selesai dan siap, produk tempe ini disalurkan ke konsumen dengan cara dijual sendiri di Pasar Pelita dan dengan cara menawarkan berkeliling dari rumah ke rumah. Daerah pemasaran agroindustri tempe UD. Rahayu ini hanya di dalam kota, yaitu dengan membuka stand di Pasar Pelita dan berkeliling di daerah Kaliwates saja.

Rantai persediaan bahan baku pada agroindustri tempe di Kabupaten Jember jika mengacu pada hasil penelitian maka menunjukkan bahwa persediaan barang hanya di bagian hulu, yaitu kedelai sebagai bahan baku utama dari agroindustri tempe yang di dapat dari pedagang kedelai, sedangkan untuk penyaluran barang oleh agroindustri tempe sampai ke konsumennya yang berbeda-beda antar agroindustri. Pola penyaluran produk tempe sebagai hasil produksi dari agroindustri tempe sampai terjual ke konsumen bervariasi, yaitu ada yang proses penyaluran tempe melalui retailer, ada yang langsung ke konsumen akhir, dan ada pula yang menggunakan metode penyaluran barang langsung ke konsumen sekaligus menyalurkan melalui retailer.

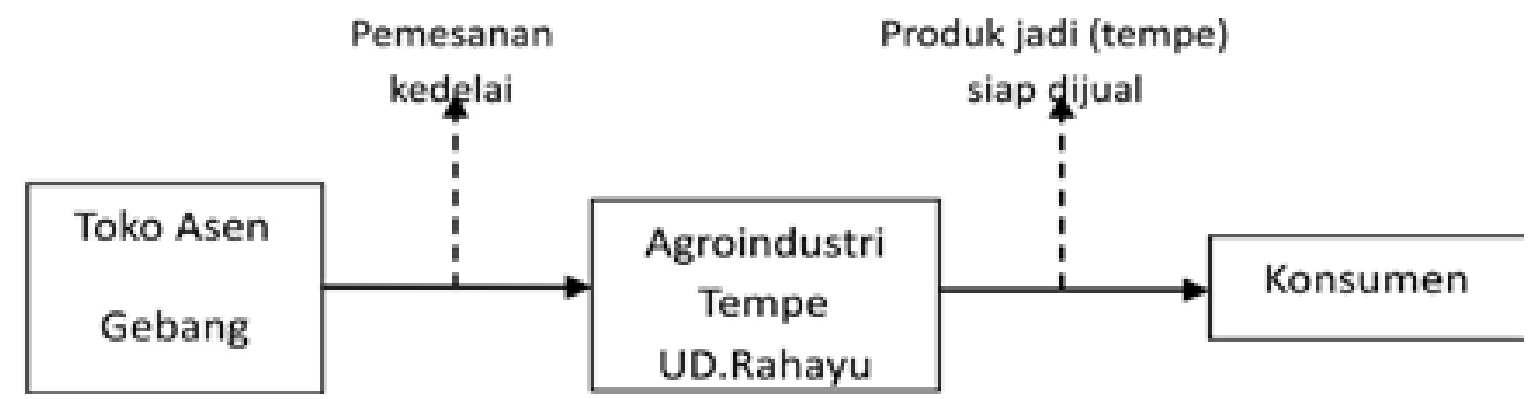

Gambar 6. Rantai Persediaan Barang (supply chain) pada Agroindustri Tempe UD. Rahayu di Kabupaten Jember 
Tingkat Pemesanan Ekonomis (Economic Order Quantity), Rentang Waktu (Lead Time) Pemesanan, dan Tingkat Pemesanan Kembali (Reorder Point) Bahan Baku (Kedelai) pada Agroindustri Tempe di Kabupaten Jember

A. Tingkat Pemesanan Ekonomis (Economic Order Quantity)

Terdapat 2 (dua) kategori skala Industri untuk agroindustri tempe di Kabupaten Jember yang diteliti dan untuk mendapatkan kedelai dengan biaya minimal maka agroindustri harus melakukan pemesanan secara ekonomis atau EOQ (Economic Order Quantity), yaitu agroindustri tempe skala industri rumah tangga dan agroindustri tempe skala industri kecil. Agroindustri tempe Makmur, Pratama, Rizqy, dan UD. Rahayu mewakili agroindustri dengan skala industri rumah tangga, sedangkan agroindustri tempe Sumber Mas mewakili untuk agroindustri dengan skala Industri kecil. Jumlah pemesanan bahan baku ekonomis pada agroindustri tempe di Kabupaten Jember dapat dilihat pada tabel 1.

Berdasarkan Tabel 1 dapat diketahui bahwa pada agroindustri tempe Makmur, agroindustri tempe Pratama, agroindustri tempe Rizqy, dan agroindustri tempe UD. Rahayu tidak terdapat biaya penyimpanan atau dapat dikatakan untuk keempat agroindustri tersebut biaya penyimpanannya adalah senilai Rp 0,00. Keempat agroindustri tersebut tidak menanggung biaya penyimpanan karena keempat agroindustri ini tidak mempunyai persediaan kedelai untuk bahan baku produksi tempe. Agroindustri-agroindustri tersebut memenuhi kebutuhan kedelai untuk produksi tempe dengan cara membeli kedelai seketika sebelum produksi, jadi kedelai yang telah dibeli dari toko habis sekaligus untuk sekali produksi. Kedelai untuk produksi selanjutnya baru akan dibeli keesokan harinya saat akan melakukan produksi lagi, begitu seterusnya. Hal ini dikarenakan jumlah kebutuhan kedelai dari masing-masing agroindustri yang masih tergolong sedikit dan dikarenakan kendala modal yang masih terbatas, alokasi dana untuk bahan baku hanya cukup untuk sekali produksi saja.

Tingkat kebutuhan kedelai pada agroindustri tempe Sumber Mas (skala industri kecil) adalah sebesar $208.800 \mathrm{~kg}$ per tahun dengan biaya pemesanan sebesar Rp 1.000,00 setiap kali melakukan pemesanan dan biaya penyimpanan sebesar Rp 9,12 per kilogram kedelai, sehingga agroindustri tersebut memiliki nilai $E O Q$ sebesar $6.766,79 \mathrm{~kg}$. Biaya penyimpanan pada agroindustri tempe Sumber Mas ini merupakan biaya yang terdiri dari biaya resiko kehilangan/ berkurangnya bahan baku akibat penyimpanan dan termasuk juga di dalamnya biaya listrik. Saat ini agroindustri tempe Sumber Mas masih melakukan pemesanan bahan baku sebesar $3.000 \mathrm{~kg}$ sekali pesan, jadi dengan adanya EOQ maka perlu dipertimbangkan penambahan kuantitas per pesanan menjadi sebesar 6.766,79 $\mathrm{kg}$ agar lebih ekonomis. Jumlah pemesanan bahan baku yang dapat meminimumkan total biaya persediaan adalah Economic Order Quantity (EOQ). Nilai $E O Q$ yang ekonomis dapat diketahui dengan membandingkan selisih total biaya kebutuhan bahan baku dengan total biaya kebutuhan ekonomis.

Agroindustri tempe Sumber Mas jika mengambil keputusan pembelian bahan baku sesuai perhitungan EOQ yaitu sebesar 6766,79 $\mathrm{kg}$ per pemesanan maka keputusan tersebut merupakan keputusan yang tepat, dikarenakan dengan memesan bahan baku sebesar $6766,79 \mathrm{~kg}$ per pesanan maka agroindustri tempe tersebut

Tabel 1. Tingkat Pemesanan Ekonomis (EOQ) pada Agroindustri Tempe di Kabupaten Jember

\begin{tabular}{lcccc}
\hline \multicolumn{1}{c}{ Agroindustri } & $\begin{array}{c}(\mathbf{S}) \\
(\mathbf{R p})\end{array}$ & $\begin{array}{c}(\mathbf{d}) \\
(\mathbf{k g} / \mathbf{t h})\end{array}$ & $\begin{array}{c}(\mathbf{H}) \\
(\mathbf{R p} / \mathbf{k g})\end{array}$ & $\begin{array}{c}(\mathbf{E O Q}) \\
(\mathbf{k g})\end{array}$ \\
\hline Skala Industri Rumah Tangga: & & & & \\
$-\quad$ Makmur & 1.000 & 27.000 & 0 & 0 \\
- Pratama & 2.500 & 36.000 & 0 & 0 \\
- Rizqy & 1.500 & 36.000 & 0 & 0 \\
- UD. Rahayu & 2.500 & 36.000 & 0 & 0 \\
Skala Industri Kecil: & & & & \\
- Sumber Mas & 1.000 & 208.800 & 9,12 & 6766,79 \\
\hline
\end{tabular}

Sumber: Data primer diolah, 2014. 
Tabel 2. Total Cost pada Agroindustri Tempe di Kabupaten Jember

\begin{tabular}{ccc}
\hline \multicolumn{1}{c}{ Agroindustri } & TC (Q) (Rp) & TC (EOQ) (Rp) \\
\hline Skala Industri Rumah Tangga: & & \\
$-\quad$ Makmur & $360.000,00$ & 0,00 \\
$-\quad$ Pratama & $900.000,00$ & 0,00 \\
$-\quad$ Rizqy & $540.000,00$ & 0,00 \\
$-\quad$ UD. Rahayu & $900.000,00$ & 0,00 \\
Skala Industri Kecil: & & \\
$-\quad$ Sumber Mas & $83.280,00$ & $61.713,14$ \\
\hline Sumber: Data primer diolah, 2014. &
\end{tabular}

dapat menghemat biaya sebesar Rp 21.566,86. Nilai selisih tersebut didapat dari selisih antara nilai TC (Q) dan TC (EOQ) pada agroindustri tempe Sumber Mas. Jika agroindustri tempe Sumber Mas menggunakan perhitungan EOQ untuk kegiatan pemesanan bahan bakunya maka dapat meminimalkan total biaya persediaan (lebih ekonomis). Sesuai hasil perhitungan, dengan adanya pemesanan bahan baku sebesar $3.000 \mathrm{~kg}$ setiap kali pesanan, dinilai tidak ekonomis karena tidak tercapai EOQ dimana total biaya pemesanan tidak sama dengan total biaya simpan.

Rata-rata rentang waktu (lead time) yang ada pada agroindustri tempe di Kabupaten Jember yang telah diteliti, adalah kurang dari 1 (satu) hari, baik untuk agroindustri skala industri rumah tangga maupun skala industri kecil. Agroindustri Sumber Mas tidak mengambil sendiri pesanannya seperti agroindustri tempe skala rumah tangga, dikarenakan jumlah pesanan yang cukup besar, akan tetapi pemesanan dilakukan via telepon dan tinggal menunggu pesanan diantarkan oleh pemasok kedelai (supplier). Semakin cepat rentang waktu untuk mendapatkan kembali bahan baku yang akan digunakan untuk produksi maka semakin baik. Jika terlalu lama rentang waktunya untuk memperoleh bahan baku yang dipesan, dapat berakibat gagal produksi.
Jumlah persediaan dimana pemesanan kembali harus dilakukan agar barang dapat diterima pada saat dibutuhkan disebut reorder point (titik pemesanan kembali). Tingkat kebutuhan kedelai selama waktu tenggang pada agroindustri tempe Makmur sebesar $75 \mathrm{~kg}$ dengan waktu tenggang 0,02 hari. Agroindustri tempe Makmur merupakan agroindustri tempe dalam skala rumah tangga yang kebutuhan bahan bakunya tergolong masih sedikit. Pemenuhan kebutuhan bahan bakunya, dalam hal ini kedelai adalah dengan cara membeli setiap hari, dan langsung digunakan seluruhnya untuk produksi.

Tingkat kebutuhan kedelai untuk produksi pada agroindustri tempe Sumber Mas sebesar $600 \mathrm{~kg}$, waktu tenggang $(0,25$ hari), persediaan yang dicadangkan (safety stock) selama menunggu pemesanan kedelai adalah sebesar $100 \mathrm{~kg}$, sehingga titik pemesanan kembali berada pada 250 $\mathrm{kg}$. Titik pemesanan kembali ini didapatkan dengan cara mengalikan jumlah kebutuhan bahan baku per produksi dengan waktu tenggang (lead time) kemudian ditambahkan dengan persediaan pengaman (safety stock). Hal ini berarti, ketika kedelai yang dimiliki agroindustri hanya sebesar $250 \mathrm{~kg}$ maka harus segera dilakukan pemesanan ulang. Jika kedelai yang dipesan terlambat

Tabel 3. Waktu Tenggang (Lead Time) pada Agroindustri Tempe di Kabupaten Jember

\begin{tabular}{ccc}
\hline No & Agroindustri & L (hari) \\
\cline { 2 - 3 } Skala & Industri Rumah Tangga: & \\
$-\quad$ Makmur & 0,02 \\
$-\quad$ Pratama & 0,02 \\
$-\quad$ Rizqy & 0,04 \\
$-\quad$ UD. Rahayu & 0,04 \\
Skala Industri Kecil: & \\
$-\quad$ Sumber Mas & 0,25 \\
\hline
\end{tabular}

Sumber: Data primer diolah, 2014. 
Tabel 4. Titik Pemesanan Kembali (Reorder Point) Kedelai pada Agroindustri Tempe di Kabupaten Jember

\begin{tabular}{|c|c|c|c|c|c|}
\hline Agroindustri & $\begin{array}{c}\mathrm{d} \\
(\mathrm{kg})\end{array}$ & $\begin{array}{c}L \\
\text { (hari) }\end{array}$ & $\begin{array}{c}S S \\
(\mathrm{~kg})\end{array}$ & $\begin{array}{c}R O P \\
\text { (kg) }\end{array}$ & $\begin{array}{c}E O Q \\
(\mathrm{~kg})\end{array}$ \\
\hline \multicolumn{6}{|c|}{ Skala Industri Rumah Tangga: } \\
\hline - Makmur & 75 & 0,02 & 0 & 1,5 & 0 \\
\hline - Pratama & 100 & 0,02 & 0 & 2,0 & 0 \\
\hline - $\quad$ Rizqy & 100 & 0,04 & 0 & 4,0 & 0 \\
\hline UD. Rahayu & 100 & 0,04 & 0 & 4,0 & 0 \\
\hline \multicolumn{6}{|l|}{ Skala Industri Kecil: } \\
\hline - $\quad$ Sumber Mas & 600 & 0,25 & 100 & 250 & 6766,79 \\
\hline
\end{tabular}

datang, maka agroindustri juga masih dapat memproduksi produk dengan menggunakan persediaan pengaman sebesar $100 \mathrm{~kg}$ kedelai, sehingga tidak akan terjadi kekurangan persediaan bahan baku (kedelai) untuk kegiatan produksi tempe.

Pada 4 (empat) agroindustri tempe skala industri rumah tangga yang juga diteliti, keempatnya sama-sama tidak memiliki stok pengaman (safety stock). Agroindustri tempe yang tidak memiliki persediaan pengaman (safety stock) mempunyai ketentuan jumlah penggunaan bahan baku atau kapasitas produksi yang cenderung konstan, pola persediaannya pun cenderung konstan, yaitu setiap hari melakukan pemesanan bahan baku dan pola penggunaan bahan baku tersebut adalah sekali habis. Hal ini juga dilatarbelakangi faktor modal yang dimiliki tidak terlalu besar, yang hanya cukup untuk rata-rata sekali produksi. Dengan demikian dapat dikatakan rentang waktu (lead time) yang ada pada agroindustri tempe di Kabupaten Jember yang telah diteliti adalah kurang dari 1 (satu) hari.

\section{SIMPULAN}

Rantai persediaan barang (supply chain) pada agroindustri tempe di Kabupaten Jember menunjukkan pola yang berbeda, yaitu (a) Pemasok kedelai- agroindustri tempe - outlet konsumen (agroindustri tempe Makmur, Rizqy) (b) pemasok kedelai - agroindustri tempe - konsumen (agroindustri tempe Makmur, Sumber Mas, Pratama, Rizqy, dan UD.Rahayu.

EOQ (Economic Order Quantity) pada agroindustri tempe di Kabupaten Jember menunjukkan hasil tidak ekonomis karena total biaya pemesanan (total ordering cost) tidak sama dengan total biaya simpan (total ordering cost); Rentang waktu (lead time) yang ada pada agroindustri tempe di Kabupaten Jember adalah 0,02 hari (agroindustri tempe Makmur), 0,25 hari (agroindustri tempe Sumber Mas), 0,02 hari (agroindustri tempe Pratama), 0,04 hari (agroindustri tempe Rizqy), dan 0,04 hari (agroindustri tempe UD.Rahayu); Titik pemesanan kembali bahan baku (kedelai) pada Agroindustri Tempe di Kabupaten Jember adalah 1,5 kg (agroindustri tempe Makmur), $250 \mathrm{~kg}$ (agroindustri tempe Sumber Mas), $2 \mathrm{~kg}$ (agroindustri tempe Pratama), $4 \mathrm{~kg}$ (agroindustri tempe Rizqy), dan $4 \mathrm{~kg}$ (agroindustri tempe UD. Rahayu).

Pelaku agroindustri tempe di Kabupaten Jember sebaiknya tetap menjaga koordinasi dan kerjasama dengan pihak-pihak yang terkait dalam rantai persediaan barang, khususnya pemasok kedelai (di bagian hulu) dan retailer/ outlet, sehingga penyaluran tempe bisa lancar sampai ke konsumen. Sebaiknya pelaku agroindustri mempunyai pencatatan sederhana yang mencatat semua biaya yang dikeluarkan pada proses produksi tempe, agar pengrajin tempe mengerti dengan tepat berapa biaya yang dikeluarkan dan berapa penerimaan yang didapat sehingga dapat diketahui keuntungan dari produksi yang dilakukan.

\section{DAFTAR PUSTAKA}

Andira, O. E. 2016. Analisis Persediaan Bahan Baku Terigu menggunakan Metode EOQ (Economic Order Quantity) pada Roti Puncak Makassar, Jurnal Ekonomi Bisnis Volume 21. No. 3.

Darmawan G.A., W. Cipta, N. Y, Yuliantini. 2015. Penerapan Economic Order Quantity (EOQ) dalam pengelolaan persediaan 
bahan baku tepung pada usaha pia Ariawan di Desa Banyuning Tahun 2013. Jurusan Manajemen. Vol. 3

Herjanto, E. 1999. Manajemen Produksi dan Operasi. Jakarta: PT. Grasindo.

Indrajit dan Djokopranoto. 2006. Konsep Manajemen Supply Chain. Jakarta: PT Grasindo.

Nazir, M. 2003. Metode Penelitian. Jakarta: Ghalia.

Riyadi, A. S. 2012, “Analisis Efisiensi Persediaan Bahan Baku Industri Abon Lele Karmina di Kabupaten Boyolali”. Jurnal Agrista.

Robyanto C.H., M. Antara, R. K. Dewi. 2013, "Analisis Persediaan Bahan Baku Tebu Pada Pabrik Gula Pandji Pt. Perkebunan Nusantara Xi (Persero) Situbondo, Jawa Timur". Jurnal Agribisnis dan Agrowisata, Vol. 2, No. 1.

Silitonga, C, Budi Santoso dan Novi Indiarto. 1996. Peranan Kedelai dalam Perekonomian Nasional dalam Ekonomi Kedelai. IPB Press. Bogor.

Sugiyono. 2006. Metode Penelitian Bisnis. Ikatan Penerbit Indonesia (IKAPI), Bandung.

Winarti, S. 1998. Tempe Adalah Antiinfeksi, Antioksidan, dan Hipolipidemik. Jember: Universitas Muhammadiyah Jember.

Yamit. 2002. Manajemen Produksi dan Operasi. Yogyakarta: Ekonisia.

Yuniasih, K.C. 2002. Analisis Usaha Pada Agroindustri Tempe Skala Kecil dan Menengah. Dalam Jurnal Agrise. Vol 1 No1 Halaman 56-73. Malang: Badan Penerbitan Fakultas Pertanian Unibraw. 